UDC 338.58: 65.014

DOI: https://doi.org/10.37320/2415-3583/11.31

Samusevych Yaryna

Candidate of Economic Sciences, Senior Lecturer,

Sumy State University

Solodukha Mariia

Student,

Sumy State University

\title{
RESEARCH OF THE IMPACT OF ENVIRONMENTAL TAXATION PARAMETERS ON THE INDICATORS OF SOCIO-ECOLOGICAL-ECONOMIC DEVELOPMENT ${ }^{1}$
}

The article is devoted to the study of the preconditions and peculiarities of the application of environmental taxation instruments for the implementation of the concept of "green" economy in the world. An analysis of world researches on the impact of environmental taxes on the indicators of sustainable development and socio-economic status has been conducted. Based on the analytical tools, a panel regression analysis of environmental taxation effects has been performed. The results of the assessment of the relationship between these indicators and the parameters of sustainable development should be the basis for the development of environmental policy aimed at reducing the burden on the environment and targeted funding for ecosystem protection. Prospects for further work are to develop guidelines for the formation of mechanisms for financial support of environmental activities and study the effectiveness of environmental and economic instruments of taxation.

Key words: environmental taxation, tax revenues, ecological culture, sustainable development.

JEL classification: M42, O31, O44, Q56.

Formulation of the problem. At present, it is extremely important for the whole world to reduce the level of environmental pollution, which is caused mainly by anthropogenic factors and causes significant damage to public health. Environmental taxes are the effective tool for this task, they are capable of integrating environmental policy objectives into the state's tax policies. The main advantages of their application include their static efficiency, which is manifested by the achievement of environmental goals in the most cost-effective way. The dynamic effectiveness of environmental taxes is determined by the creation of a permanent incentive for taxpayers to reduce their tax base through the possibility of cost savings due to the reduction of environmental tax obligations. This leads to a reduction of environmental pollution in the long run. The application of environmental taxes implements the guiding principle of environmental policy: "polluter and user pay full price". The study of environmental taxes on compliance with this principle of environmental policy is extremely important in the context of the successful implementation of Ukraine's Environmental Strategy until 2030. This principle should be applied systematically and without exception to all sources of emissions, whether stationary or mobile, equally to individuals and legal entities.

Analysis of recent research and publications, highlighting previously unresolved issues. Edenhofer et al. [4] believe that fiscal reforms in the field of environmental taxation that reduce subsidies and increase tax rates will not only help mitigate climate change, but can also increase the economic efficiency of national tax systems and provide additional government revenue that can be used to help human development.

In their work, Shmelev and Speck used an econometric approach to analyze the effectiveness of energy and carbon taxes in Sweden, one of the first countries to introduce a $\mathrm{CO} 2$ tax, and to evaluate the impact of extensive environmental tax reform in that country. The results showed that the $\mathrm{CO} 2$ tax alone was not sufficient to cause a significant change in $\mathrm{CO} 2$ emissions in Sweden, except in the case of gasoline. On the other hand, taxes on energy, coal and liquefied gas were statistically significant. It was also understood that technological innovations in the form of nuclear and hydropower development had played a significant role in reducing $\mathrm{CO} 2$ emissions in Sweden, as well as raising oil prices $[9,1]$. A domestic scientist Novitskaya [7] found that energy taxes had the most significant impact on the divergence of resource consumption, environmental burden and economic growth.

Using a distributed lag analysis, Rochie [8] has found that environmental tax has an impact on environmental costs and environmental innovation with a 4 -year grace period. Based on the simulation results, it has been found that a $1 \%$ increase in environmental tax revenue leads to a $3.2 \%$ reduction in eco-innovation. This indicates that the dynamic effectiveness

${ }^{1}$ The paper was supported by the Ministry of Education and Science of Ukraine and performed the results of the project "Structuralfunctional multiplex model of ecological tax system building in Ukraine in the context of national security" (registration number 0119U100759). 
of the environmental tax has not emerged, and environmental taxation is not currently a strong stimulus motivator for innovation.

Kararo et al. [6] have argued that the "employment double-dividend hypothesis" implies that an environmentally friendly fiscal reform has been devised, whereby emissions costs are used to subsidize employers' social security contributions, can implement (at least) two relevant policy objectives: improving the quality of the environment and, at the same time, increasing employment.

The European countries have expanded the use of the environmental taxation instruments by creating new tax bases. Chiroleu-Assouline and Fodha have evaluated whether there can be an improvement in Pareto's environmental tax reform when pollution tax revenues are reworked by changing the properties of the labor tax. They have shown that, regardless of the degree of environmental tax regression, a recycling mechanism can be devised that will make tax reform more effective while reducing wage tax and increasing its variability [3].

Kremer et al. [2] have built a model with four groups of households that have benefits in terms of labor supply, consumption of polluting (energy) and non-polluting (non-energy) goods and emissions. They quantify the model for the French economy and calculate its optimal tax equilibrium under the nine best tax regimes. It has emerged that the redistributive role of environmental taxes requires that polluting goods be taxed at a rate far below marginal social damage.

Rapanos [11] states that pollution taxes are one of the tools that are often proposed to reduce pollution. In his study, he examines the impact of consumption taxes on polluting industries, factor and commodity prices, and products. The analysis shows that standard neoclassical models of tax cases may not be adequate in the study of the above effects, and that a clear inclusion of external factors of influence is required.

The purpose of the article is to study the prerequisites and features of the use of environmental taxation instruments to implement the concept of a "green" economy in the world and assess the impact of environmental taxation instruments on the indicators of socio-ecological-economic development.

Presenting main material. Many domestic and foreign scientists have determined that environmental taxation is intended to stimulate the mass introduction of innovative technologies, to promote the implementation of environmental policy programs in all countries, to ensure the efficiency of the bodies of the fiscal service, to stimulate the modernization of all spheres of human life to preserve the environment for future generations.

To assess the impact of environmental taxation on environmental performance, a panel regression analysis has been applied using Stata software, which allowed to estimate the average linkage rate for a sample of 7 countries (Ukraine, Poland, the Czech Republic, Latvia, France, Belarus, the Slovak Republic) over the study period covering 2009-2018.

The following indicators of environmental taxation have been selected for the study: the share of environmental taxes in tax revenues (The share of ET

Table 1 - Results of estimation of influence of environmental taxation parameters on indicators of socio-ecological-economic development for the period 2009-2018.

\begin{tabular}{|c|c|c|c|c|c|c|}
\hline Factor variables & Coefficient & Standard error & $\mathbf{Z}$ & $\mathbf{P}>|\mathbf{z}|$ & Lower 95\% & Top 95\% \\
\hline \multicolumn{7}{|c|}{ Unemployment rate } \\
\hline The share of ET in TR & -0.813 & 0.483 & -1.680 & 0.092 & -1.759 & 0.133 \\
\hline The share of ET in GDP & -1.308 & 1.450 & -0.900 & 0.367 & -4.150 & 1.534 \\
\hline \multicolumn{7}{|c|}{ The level of innovation of enterprises } \\
\hline The share of ET in TR & 0.263 & 0.108 & 2.430 & 0.015 & 0.051 & 0.476 \\
\hline The share of ET in GDP & 0.778 & 0.300 & 2.590 & 0.010 & 0.189 & 1.367 \\
\hline \multicolumn{7}{|c|}{ The share of the working population } \\
\hline The share of ET in TR & 0.118 & 0.048 & 2.440 & 0.015 & 0.023 & 0.212 \\
\hline The share of ET in GDP & 0.224 & 0.159 & 1.410 & 0.158 & -0.087 & 0.535 \\
\hline \multicolumn{7}{|c|}{ Health care } \\
\hline The share of ET in TR & -76.901 & 61.554 & -1.250 & 0.212 & -197.545 & 43.742 \\
\hline The share of ET in GDP & -266.504 & 193.560 & -1.380 & 0.169 & -645.875 & 112.868 \\
\hline \multicolumn{7}{|c|}{ Energy consumption } \\
\hline The share of ET in TR & -0.005 & 0.045 & -0.120 & 0.903 & -0.093 & 0.082 \\
\hline The share of ET in GDP & -0.073 & 0.135 & -0.540 & 0.589 & -0.338 & 0.192 \\
\hline \multicolumn{7}{|c|}{ Healthy life expectancy } \\
\hline The share of ET in TR & -0.179 & 0.155 & -1.160 & 0.247 & -0.482 & 0.124 \\
\hline The share of ET in GDP & -0.061 & 0.472 & -0.130 & 0.898 & -0.987 & 0.865 \\
\hline
\end{tabular}

Source: authors' calculations based on the data [6;10; 12] 
Table 2 - Results of estimation of influence of environmental taxation parameters on indicators of socio-ecological-economic development for the period 2009-2018 with a time lag of one year

\begin{tabular}{|c|c|c|c|c|c|c|}
\hline Factor variables & Coefficient & Standard error & $\mathbf{Z}$ & $\mathbf{P}>|\mathbf{z}|$ & Lower 95\% & Top 95\% \\
\hline \multicolumn{7}{|c|}{ Unemployment rate } \\
\hline The share of ET in TR & -0.337 & 0.515 & -0.650 & 0.513 & -1.346 & 0.672 \\
\hline The share of ET in GDP & 0.026 & 1.410 & 0.020 & 0.985 & -2.740 & 2.790 \\
\hline Increase in ET & 0.002 & 0.037 & 0.060 & 0.954 & -0.070 & 0.074 \\
\hline \multicolumn{7}{|c|}{ The level of innovation of enterprises } \\
\hline The share of ET in TR & 0.135 & 0.110 & 1.220 & 0.223 & -0.082 & 0.351 \\
\hline The share of ET in GDP & 0.449 & 0.286 & 1.570 & 0.117 & 0.112 & 1.009 \\
\hline Increase in ET & -0.020 & 0.008 & -2.480 & 0.013 & -0.036 & -0.004 \\
\hline \multicolumn{7}{|c|}{ The share of the working population } \\
\hline The share of ET in TR & 0.047 & 0.058 & 0.810 & 0.416 & -0.066 & 0.160 \\
\hline The share of ET in GDP & -0.022 & 0.170 & -0.130 & 0.899 & -0.354 & 0.311 \\
\hline Increase in ET & 0.000 & 0.004 & 0.120 & 0.908 & -0.007 & 0.008 \\
\hline \multicolumn{7}{|c|}{ Health care } \\
\hline The share of ET in TR & -53.064 & 59.746 & -0.890 & 0.374 & -170.164 & 64.035 \\
\hline The share of ET in GDP & -63.344 & 174.858 & -0.360 & 0.717 & -406.058 & 279.371 \\
\hline Increase in ET & 2.829 & 3.865 & 0.730 & 0.464 & -4.746 & 10.404 \\
\hline \multicolumn{7}{|c|}{ Energy consumption } \\
\hline The share of ET in TR & -0.014 & 0.048 & -0.300 & 0.767 & -0.108 & 0.079 \\
\hline The share of ET in GDP & -0.045 & 0.138 & -0.320 & 0.746 & -0.315 & 0.226 \\
\hline Increase in ET & 0.002 & 0.003 & 0.500 & 0.620 & -0.005 & 0.008 \\
\hline \multicolumn{7}{|c|}{ Healthy life expectancy } \\
\hline The share of ET in TR & -0.178 & 0.166 & -1.070 & 0.284 & -0.504 & 0.148 \\
\hline The share of ET in GDP & -0.011 & 0.479 & -0.020 & 0.982 & -0.950 & 0.928 \\
\hline Increase in ET & -0.012 & 0.012 & -1.040 & 0.297 & -0.035 & 0.011 \\
\hline
\end{tabular}

Source: authors' calculations based on the data $[6 ; 10 ; 12]$

Table 3 - Results of estimation of influence of environmental taxation parameters on indicators of socio-ecological-economic development for the period 2009-2018 with a time lag of three years

\begin{tabular}{|c|c|c|c|c|c|c|}
\hline Factor variables & Coefficient & Standard error & $\mathbf{Z}$ & $\mathbf{P}>|\mathbf{z}|$ & Lower 95\% & Top 95\% \\
\hline \multicolumn{7}{|c|}{ Unemployment rate } \\
\hline The share of ET in TR & 0.350 & 0.567 & 0.620 & 0.537 & -0.761 & 1.460 \\
\hline The share of ET in GDP & 0.806 & 1.365 & 0.590 & 0.555 & -1.868 & 3.481 \\
\hline Increase in ET & -0.012 & 0.030 & -0.410 & 0.680 & -0.072 & 0.047 \\
\hline \multicolumn{7}{|c|}{ The level of innovation of enterprises } \\
\hline The share of ET in TR & 0.098 & 0.114 & 0.860 & 0.390 & -0.125 & 0.321 \\
\hline The share of ET in GDP & 0.298 & 0.269 & 1.110 & 0.269 & -0.230 & 0.826 \\
\hline Increase in ET & -0.019 & 0.006 & -3.330 & 0.001 & -0.031 & -0.008 \\
\hline \multicolumn{7}{|c|}{ The share of the working population } \\
\hline The share of ET in TR & 0.015 & 0.058 & 0.260 & 0.796 & -0.098 & 0.128 \\
\hline The share of ET in GDP & -0.028 & 0.143 & -0.190 & 0.847 & -0.308 & 0.253 \\
\hline Increase in ET & -0.002 & 0.003 & -0.580 & 0.563 & -0.007 & 0.004 \\
\hline \multicolumn{7}{|c|}{ Health care } \\
\hline The share of ET in TR & 86.771 & 92.831 & 0.930 & 0.350 & -95.175 & 268.717 \\
\hline The share of ET in GDP & 292.486 & 229.251 & 1.280 & 0.202 & -156.838 & 741.810 \\
\hline Increase in ET & -1.159 & 4.567 & -0.250 & 0.800 & -10.110 & 7.793 \\
\hline \multicolumn{7}{|c|}{ Energy consumption } \\
\hline The share of ET in TR & 0.086 & 0.052 & 1.640 & 0.101 & -0.017 & 0.189 \\
\hline The share of ET in GDP & 0.300 & 0.144 & 2.080 & 0.038 & 0.017 & 0.583 \\
\hline Increase in ET & 0.002 & 0.004 & 0.460 & 0.644 & -0.005 & 0.009 \\
\hline \multicolumn{7}{|c|}{ Healthy life expectancy } \\
\hline The share of ET in TR & -0.244 & 0.196 & -1.250 & 0.213 & -0.628 & 0.140 \\
\hline The share of ET in GDP & 0.036 & 0.542 & 0.070 & 0.947 & -1.026 & 1.098 \\
\hline Increase in ET & -0.007 & 0.014 & -0.490 & 0.621 & -0.035 & 0.021 \\
\hline
\end{tabular}

Source: authors' calculations based on the data [6; 10; 12] 
in TR), the share of environmental taxes in GDP (The share of ET in GDP), increase in environmental taxes (Increase in ET). The results of assessing the impact of environmental taxation parameters and indicators of socio-ecological-economic development on the basis of annual observations are presented in Table 1.

The above calculation results show that there is a close relationship between the investigated indicators. Thus, the share of environmental taxes in GDP and aggregate tax revenues have a significant impact on most indicators of socio-ecological-economic development, namely unemployment and innovation and healthy life expectancy. Firstly, this is due to the process of improving these parameters at the expense of these revenues. This means reducing the amount of harmful use of the environment, which testifies to the complexity of the country's environmental policy.

The effect of environmental taxes in the year after their application is somewhat worsening, but it also maintains a positive interaction dynamic. The close correlation between the increase in environmental taxes and the cost of innovation shows that this is improving by transforming some businesses and moving them to new technologies (Table 2).

The increase of effectiveness of environmental tax indicators in GDP, and tax revenues, and environmental tax is confirmed in relation to all selected parameters of socio-ecological-economic development, which indicates the significant impact of such indicators on the sustainability of socio-ecological-economic processes in this country samples again. An assessment of the impact on sustainability indicators of human development in the three-year perspective has revealed an improvement in the relationship between environmental tax increases and the innovation rate, as well as the share of environmental taxes in GDP and energy consumption (Table 3).
These results suggest that the desired effect of using environmental benefits can be obtained in three years.

Conclusion. The results of assessing the impact of environmental revenues on indicators of socio-ecological-economic development show that:

- unemployment rate changes due to environmental tax revenues increases with lag in one and three years;

- the level of innovations increases every year after the changes in environmental taxes;

- the indicator of working capacity decreases in a year or with a lag in one year after the changes of environmental policy, but reaches its minimum with a lag in three years;

- the health index decreases in a year of implementation the changes in environmental taxes and with a lag of three years, but increases rapidly with a lag of one year;

- the indicator of energy consumption decreases in a year of increase in environmental taxes and increases with a lag in one and three years;

- healthy life expectancy is almost unchanged in the year of environmental taxes growth and with a lag of one year, and this indicator tends to increase with a lag of three years.

From the analysis of the interaction between selected indicators, it follows that indicators of the use of environmental taxes significantly affect the general parameters of population health, efficiency, unemployment and innovation. Therefore, the use of environmental and economic taxation instruments will contribute to the effective implementation of environmental policy, creation additional incentives to limit the production and economic activity of economic entities that are harmful to the environment.

\section{References:}

1. Bach S. The effects of environmental fi scal reform in Germany: a simulation study. Elsevier Energy Policy. 2002. Vol. 30. Iss. 9, P. 803-811 (accessed 23 February 2020).

2. Bruce M. Empirical evidence on the effectiveness of environmental taxes. Applied Economics Letters. 2012. Vol. 19. Issue 18. P. 1817-1820 (accessed 26 February 2020).

3. Carraro C., Galeotti M., Gallo M. Environmental taxation and unemployment: Some evidence on the 'double dividend hypothesis' in Europe. Journal of Public Economics. 2006. Vol. 62. Issues 1-2. P. 141-181 (accessed 21 February 2020).

4. Edenhofer O., Jakob M., Creutzig F., Flachsland C., Fuss S., Kowarsch, Kai Lessmann M., Mattauch L., Siegmeier J., and Steckel C. Closing the Emission Price Gap. Global Environmental Change. 2015. Vol. 31. P. 132-143 (accessed 23 February 2020).

5. Environmental tax statistics. Eurostat. URL: http://ec.europa.eu/eurostat/statistics-explained/index.php/Environmental_ tax_statistics (accessed 25 February 2020).

6. Cremer H., Gahvari F., Ladoux N. Environmental taxes with heterogeneous consumers: an application to energy consumption in France. Journal of Public Economics. 2013. Vol. 87. Issue 12. P. 2791-2815 (accessed 27 February 2020).

7. Novytska N.V. European practice in excise taxation on mineral oil products. Management and Development of Financial Systems in Eastern European Countries Current State and Problems. 2013. № 4. P. 235-242 (accessed 20 February 2020)

8. Rocchi P. et al. The reform of the European energy tax directive: exploring the potential economic impacts in the EU27. Energy Policy. 2014.Vol. 75. P. 341-353 (accessed 23 February 2020).

9. Shmelev S., Speck S. Green fiscal reform in Sweden: An econometric assessment of the carbon and energy taxation scheme. Elsevier Renewable and Sustainable Energy Reviews. 2018. Vol. 90. URL: https://doi.org/10.1016/j.rser.2018.03.032 (accessed 29 February 2020)

10. Sustainable Society Index. Sustainable Society Foundation. URL: http://www.ssfindex.com/data-all-countries/ (accessed 25 February 2020). 
11. Rapanos V. The effects of environmental taxes on income distribution. European Journal of Political Economy. 1995. Vol. 11. Issue 3. P. 487-501 (accessed 23 February 2020).

12. World Development Indicators. The World Bank. URL: http://databank.worldbank.org/data/reports.aspx?source= world-development-indicators (accessed 25 February 2020).

\section{Список використаних джерел:}

1. Bach S. The effects of environmental fi scal reform in Germany: a simulation study. Elsevier Energy Policy. 2002. Vol. 30. Iss. 9, P. 803-811 (дата звернення 23.02.2020)..

2. Bruce M. Empirical evidence on the effectiveness of environmental taxes. Applied Economics Letters. 2012. Vol.19. Issue 18. P. 1817-1820 (дата звернення 26.02.2020)..

3. Carraro C., Galeotti M., Gallo M. Environmental taxation and unemployment: Some evidence on the 'double dividend hypothesis' in Europe. Journal of Public Economics. 2006. Vol. 62. Issues 1-2. P. 141-181 (дата звернення 21.02.2020).

4. Edenhofer O., Jakob M., Creutzig F., Flachsland C., Fuss S., Kowarsch, Kai Lessmann M., Mattauch L., Siegmeier J., and Steckel C. Closing the Emission Price Gap. Global Environmental Change. 2015. Vol. 31. Р. 132-143 (дата звернення 23.02.2020)..

5. Environmental tax statistics. Eurostat. URL: http://ec.europa.eu/eurostat/statistics-explained/index.php/Environmental_ tax_statistics (дата звернення 25.02.2020).

6. Cremer H., Gahvari F., Ladoux N. Environmental taxes with heterogeneous consumers: an application to energy consumption in France. Journal of Public Economics. 2013. Vol. 87. Issue 12. P. 2791-2815 (дата звернення 27.02.2020).

7. Novytska N.V. European practice in excise taxation on mineral oil products. Management and Development of Financial Systems in Eastern European Countries Current State and Problems. 2013. № 4. Р. 235-242 (дата звернення 20.02.2020).

8. Rocchi P. et al. The reform of the European energy tax directive: exploring the potential economic impacts in the EU27. Energy Policy. 2014.Vol. 75. P. 341-353 (дата звернення 23.02.2020).

9. Shmelev S., Speck S. Green fiscal reform in Sweden: An econometric assessment of the carbon and energy taxation scheme. Elsevier Renewable and Sustainable Energy Reviews. 2018. Vol. 90. URL: https://doi.org/10.1016/j.rser.2018.03.032 (дата звернення 29.02.2020)

10. Sustainable Society Index. Sustainable Society Foundation. URL: http://www.ssfindex.com/data-all-countries/ (дата звернення 25.02.2020).

11. Rapanos V. The effects of environmental taxes on income distribution. European Journal of Political Economy. 1995. Vol. 11. Issue 3. P. 487-501(дата звернення 23.02.2020)..

12. World Development Indicators. The World Bank. URL: http://databank.worldbank.org/data/reports.aspx?source= world-development-indicators (дата звернення 25.02.2020).

Самусевич Я.В., Солодуха М.В.

Сумський державний університет

\section{ДОСЛІДЖЕННЯ ВПЛИВУ ПАРАМЕТРІВ ЕКОЛОГІЧНОГО ОПОДАТКУВАННЯ НА ІНДИКАТОРИ СОЦІО-ЕКОЛОГО-ЕКОНОМІЧНОГО РОЗВИТКУ}

Стаття присвячена дослідженню передумов та особливостей застосування еколого-економічних інструментів оподаткування для провадження концепиії «зеленої» економіки у світі. Проведено аналіз світових досліджень щодо впливу екологічного податку на показники сталого розвитку та сочіально-економічного становища. Досліджено як екологічні податки впливають на сочіо-еколого-економічні показники. На основі аналітичних інструментів було проведено панельний регресійний аналіз впливу оподаткування навколишнього середовища. Виходячи з розрахунків, можна сказати, щзо найбільш ефективно доходи від екологічних надходжень використовуються протягом наступних трьох років. Саме у трирічній перспективі показники сталого екологічного, економічного та людського розвитку наростаючим підсумком відтворюють позитивну динаміку тісних взаємозв'язків. Оиінювання взаємозв'язку иих показників та параметрів сталого розвитку має бути покладено в основу розробки екологічної політики, спрямованої на зменшення навантаження на навколишнє природнє середовище та цільового фінансування захисту екосистеми за рахунок надходжень від сплати екологічних податків. 3 аналізу взаємодіі показників випливає, щуо показники використання екологічних податків суттєво впливають на загальні параметри здоров'я населення, ефективності, безробіття та інновацій, щзо доводить, щзо для підвищення екологічної безпеки краӥн необхідно враховувати вплив усіх видів показників, включаючи демографічні показники в краӥні та забезпечення населення якісними ресурсами. 3'ясовано, що застосування еколого-економічних інструментів оподаткування сприятиме ефективній реалізації екологічної політики, створенню додаткових стимулів щодо обмеження виробничо-господарської діяльності суб'єктів господарювання, яка завдає шкоди довкіллю, та формуванню достатніх матеріальних ресурсів для здійснення природоохоронних програм. Перспективи подальших напрацювань полягають у розробленні методичних засад формування механізмів фінансового забезпечення природоохоронної діяльності та дослідженні ефективності провадження еколого-економічних інструментів оподаткування.

Ключові слова: екологічне оподаткування, податкові надходження, екологічна культура, сталий розвиток. 